\title{
Predatory behaviour and selectivity of a primary piscivore: comparison of fish and non-fish prey
}

\author{
Francis Juanes*, Jeffrey A. Buckel ${ }^{* *}$, Frederick S. Scharf \\ Department of Natural Resources Conservation, University of Massachusetts, Amherst, Massachusetts 01003-4210, USA
}

\begin{abstract}
Young-of-the-year (YOY) bluefish Pomatomus saltatrix become piscivorous at about $40 \mathrm{~mm}$ total length, coinciding with a habitat shift from offshore waters to estuarine nursery areas. Although YOY bluefish are primarily piscivorous in estuarine waters, shrimp prey can often be an important component of diets in mid-summer. In this study, we first compare the feeding behaviour and prey selection patterns of bluefish feeding on fish Menidia menidia and sand shrimp Crangon septemspinosa prey in a series of laboratory experiments, and then assess prey-type selectivity in the field. Compared to consuming fish prey, ingesting shrimp prey involved added manipulation and close inspection by the predator. Feeding on shrimp prey resulted in lower attack success rates, longer handling times, and lower relative profitabilities than feeding on fish prey. When given a choice, bluefish selectively ingested fish prey over similarly-sized shrimp prey. The results of these experiments suggest that species-specific differences in prey response lead to the observed differences in predator behaviour and selectivity. Examination of field-collected spring-spawned bluefish showed that their diet was dominated by fishes; however, sand shrimp were important prey in early summer. Selectivity index values showed that bluefish exhibited positive selection for fishes and avoidance of shrimp. The occurrence of shrimp in bluefish diets probably results from high relative abundance of shrimp and the small size of shrimp relative to fish prey. We conclude that the timing of bluefish entry into estuaries relative to peaks in abundance of various prey could have a strong effect on bluefish size at the end of the growing season and, therefore size-dependent survival.
\end{abstract}

KEY WORDS: Bluefish · Crangon septemspinosa $\cdot$ Menidia menidia $\cdot$ Piscivory $\cdot$ Pomatomus saltatrix · Predation $\cdot$ Prey selectivity $\cdot$ Shrimp prey Resale or republication not permitted without written consent of the publisher

\section{INTRODUCTION}

Prey selection by predators is an important mechanism structuring aquatic communities. Piscivorou fishes are usually near the top of most aquatic trophic webs and can have strong effects on prey morphology (Brönmark \& Miner 1992, Poleo et al. 1995), life history (Rodd \& Reznick 1997, Johnson \& Belk 1999), and community structure (Hambright 1994). Removal or addition of piscivores in many systems leads to cascading community effects (Carpenter \& Kitchell 1993, Mittel-

\footnotetext{
*E-mail: juanes@forwild.umass.edu

** Present address: Department of Zoology, Center for Marine Sciences and Technolgy, North Carolina State University, Morehead City, North Carolina 28557, USA
}

bach et al. 1995, Jennings \& Kaiser 1998). Direct and indirect community effects are a result of consistent prey type and size selectivities exhibited by most piscivores (Juanes 1994, Ellis \& Gibson 1995, 1997, Sogard 1997). For example, in temperate estuarine systems, predators can change the prey fish species composition in experimental predator treatments and also alter the size distribution of some prey species compared to predator-free controls (Wright et al. 1993). Similar effects have been observed in coral reef systems (Carr \& Hixon 1995, Beets 1997, Connell 1998). It is important to understand the mechanisms underlying observed prey selectivities in order to predict community changes in response to variations in predator abundances.

Most piscivorous fishes undergo ontogenetic shifts in diet (Werner \& Gilliam 1984, Keast 1985, Mittelbach et 
al. 1988, Post et al. 1997). These shifts generally progress from zooplankton to benthic macrofauna or prey fishes with a concomitant increase in mean prey size as predators grow (Scharf et al. 1998a). Primary piscivores become piscivorous in the first few months of life (Keast 1985). The timing of the shift to piscivory depends on predator and prey phenologies and invariably results in an increase in predator growth rate (Malmquist et al. 1992, Fitzhugh et al. 1996, Olson 1996). However, even the largest predators retain a portion of non-fish prey in their diet (Chapman et al. 1989, Eggleston et al. 1998, Beaudoin et al. 1999). This diet breadth has been attributed to the flexibility and trophic adaptability of fish-feeding (Dill 1983, Gerking 1994). However, few studies exist that compare the predation mechanics and the ecological consequences of flexible feeding in piscivorous fishes.

Young-of-the-year (YOY) bluefish (Pomatomus saltatrix) become piscivorous at about $40 \mathrm{~mm}$ total length (TL) (Marks \& Conover 1993). This feeding shift coincides with a habitat shift from offshore waters to estuarine nursery areas where they feed on abundant inshore fishes (Juanes et al. 1993, 1994, Juanes \& Conover 1995). Although primarily piscivorous, shrimp (particularly the sand shrimp Crangon septemspinosa and the grass shrimp Palaemonetes vulgaris) can be an important part of the diet in mid-summer (Friedland et al. 1988, Creaser \& Perkins 1994, Juanes \& Conover 1995, Buckel \& Conover 1997). In years where shrimp consumption is prevalent, growth tends to be reduced (Friedland et al. 1988). Results of laboratory experiments support this finding, as juvenile bluefish grow faster feeding on fish prey than on crustacean prey (Juanes \& Conover 1994b). Recent work has shown that size-based predation components (e.g. attack success, handling times, prey profitability) can vary substantially for different teleost prey types due to prey-specific morphological and behavioural differences (Scharf et al. 1998b). However, rarely has predation by a primary piscivore on prey types as different as shrimp and fishes been experimentally compared.

Here, we compare the feeding behaviour and foraging components of bluefish feeding on fish and shrimp prey. We also measure prey-size selectivity of YOY bluefish feeding on shrimp, and selectivity between shrimp and fish prey. In addition, we test our laboratory results in the field by examining the selectivity of YOY bluefish on fish and shrimp prey in Great South Bay (GSB), Long Island, New York.

\section{MATERIALS AND METHODS}

Laboratory experiments. We used Atlantic silversides, Menidia menidia, as the fish prey and sand shrimp Crangon septemspinosa as the shrimp prey. Previous field work has shown that Pomatomus saltatrix diets are dominated by silversides in various estuaries along the Atlantic coast (Grant 1962, McDermott 1983, Friedland et al. 1988, Juanes et al. 1994, Juanes \& Conover 1995) and that sand shrimp also constitute a substantial portion of the stomach contents in some months (Creaser \& Perkins 1994, Juanes \& Conover 1994a, 1995).

Bluefish, silversides, and shrimp were collected by seining from GSB and were transported to the Flax Pond Marine Laboratory (Old Field, New York), where they were allowed to acclimate for $1 \mathrm{wk}$ prior to use in experiments. The experiments were conducted in 4001 flow-through tanks $(121 \times 64 \times 58 \mathrm{~cm})$ with a Plexiglas front window, kept under a constant light regime (14 L:10 D) and at constant temperature $\left(20\right.$ to $\left.23^{\circ} \mathrm{C}\right)$. Each tank was illuminated by two $200 \mathrm{~W}$ bulbs placed overhead and providing diffuse light. Seawater was filtered using a sand-filter and was therefore of low turbidity.

Behavioural experiments were performed with groups of 3 similarly-sized predators and multiple prey. Bluefish were starved for $24 \mathrm{~h}$ between feeding trials. Behaviours were recorded using a video camera filming at 30 frames $\mathrm{s}^{-1}$ and positioned $1 \mathrm{~m}$ in front of the tank. Prey were added to a transparent Plexiglas container within the tank already containing bluefish and allowed to acclimate. Trials began when the prey container was removed, allowing bluefish access to the prey, and ended when bluefish had filled their guts and stopped feeding (usually 15 to $20 \mathrm{~min}$ ).

We conducted 3 types of behavioural experiments. The first set of experiments used similarly-sized fish and shrimp prey separately to compare predation components (e.g. handling times, capture success rates and prey profitability), the second used 2 shrimp sizes simultaneously to measure prey-size selectivity, and the third used similarly-sized shrimp and fish prey simultaneously to measure prey-type selectivity.

To measure predation components, we subdivided bluefish into 2 size groups: small (90 to $120 \mathrm{~mm}$ (TL) and large (130 to $160 \mathrm{~mm} \mathrm{TL}$ ). We used silversides and shrimp prey of a similar size (20 to $40 \mathrm{~mm} \mathrm{TL}$, for shrimp prey, measured from rostrum to tail). For these experiments, we added 10 to 15 individual prey items of 1 prey type to the experimental tanks as described above.

The following parameters were measured from the video analysis: handling time defined as the time to bite into and swallow the prey, and attack success defined as 0 if the prey escaped or was missed, or 1 if the prey was ingested. Attack success within a trial was calculated as the percent of attacks that were successful. After testing for normality (Kolmogorov-Smirnov test) and for homogeneity of variances (Bartlett's 
test), ANOVAs were run on $\log _{10}(\mathrm{x}+1)$-transformed mean handling times and percent attack success to assess the effects of predator size and prey type.

Size-specific prey profitabilities $\left(\mathrm{J} \mathrm{s}^{-1}\right)$ were calculated as the ratio of energy content of a prey type to the mean handling time of the predator-prey type combination. Prey energy content was determined for the average prey size within a size class (i.e. $30 \mathrm{~mm}$ TL) based on weights obtained from length-weight regressions (Juanes \& Conover 1994b), and prey-specific caloric content (Steimle \& Terranova 1985). We assumed that encounter rates (and therefore search times) and energetic costs of attack were independent of prey size.

Prey-size selection experiments were conducted by offering 3 groups of 3 similarly-sized bluefish (TL $=90$ to $120 \mathrm{~mm}$ TL) mixtures of 15 small (20 to $40 \mathrm{~mm}$ TL) and 15 large (50 to $70 \mathrm{~mm}$ TL) sand shrimp. Prey were available for $24 \mathrm{~h}$, after which all prey were removed and noted. The experiment was repeated 14 times by picking a new set of similarly-sized prey and adding them to the predator tanks. To assess selectivity between fish and shrimp prey, we offered 2 groups of 3 bluefish (60 to $90 \mathrm{~mm}$ TL) a mixture of 12 silversides and 12 shrimp of similar size (20 to $40 \mathrm{~mm}$ TL) and proceeded as above. Predator and prey sizes chosen were based on size distributions in previous field collections (see Juanes \& Conover 1995) and therefore represented size combinations occurring naturally in the environment.

Prey size- and type-selection data were analyzed using a chi-square test to detect differences from a random choice (Zar 1984).

Field collections and diet analysis. YOY bluefish and their potential fish prey were collected with a $30 \times$ $2 \mathrm{~m}$ beach seine (6 $\mathrm{mm}$ mesh wings, $3 \mathrm{~mm}$ mesh bag) on 4 dates in 1999 (June 30, July 8, July 22, August 5) in GSB. All species were identified and enumerated from the first seine haul; additional seine hauls were conducted to obtain a larger sample size of bluefish. We sampled at 5 sites within GSB that covered $50 \mathrm{~km}$ east to west. The seine was set parallel to the beach at a known distance offshore and the ends of the seine brought to the beach. The area that the beach seine swept was calculated using seine length, distance offshore, and the distance between the ends of the seine at the beach. Potential shrimp prey were quantified using a $1 \mathrm{~m}$ beam trawl which was hauled by hand for a known distance.

Bluefish taken for stomach-content analysis were wet-weighed $( \pm 0.1 \mathrm{~g})$ and TL measured $( \pm 1.0 \mathrm{~mm})$. Stomachs were removed and preserved in $10 \%$ formalin. Stomach contents were identified to the lowest possible taxon, blotted dry, weighed $( \pm 0.01 \mathrm{~g})$, and TL measured. Frequency of occurrence (F) was calculated as the number of stomachs in which a prey occurred divided by the total number of stomachs containing food. The weight of each prey type was divided by the total weight of all prey types to calculate prey contribution by weight (W).

The feeding selectivity of spring-spawned bluefish was determined from the relative abundance of prey in bluefish stomachs and the relative abundance of prey in seine and beam trawl catches. Fish (primarily Atlantic silverside; bay anchovy, Anchoa mitchilli, and Atlantic menhaden, Brevoortia tyrannus) and shrimp (sand shrimp and grass shrimp, Palaemonetes vulgaris) prey categories were examined. A selectivity index value was calculated for only those stations where diet information from at least 3 spring-spawned bluefish was available. Chesson's (1978) index was used to determine bluefish prey selectivity at each station as:

$$
\alpha_{i}=\frac{r_{i} / p_{i}}{\sum_{j=1}^{m} r_{j} / p_{j}}, \quad i=1, \ldots, m
$$

where $\alpha_{i}$ is the selectivity for prey type $i, r_{i}$ is the relative abundance of prey type $i$ in bluefish stomachs, $p_{i}$ is the relative abundance of prey type $i$ in the environment, and $m$ is the number of prey types available. Values of $\alpha_{i}$ were averaged for each date. Random feeding occurs when mean $\alpha_{i}=m^{-1}$; in our study, values of $\alpha_{i}>0.5$ or $\alpha_{i}<0.5$ represent 'selection' and 'avoidance' of prey, respectively. Random feeding was tested by a Student's $t$-test to compare mean $\alpha_{i}$ to 0.5 (Chesson 1983).

\section{RESULTS}

\section{Lab experiments}

Compared to consuming fish (Menidia menidia) prey, ingesting shrimp (Crangon septemspinosa) prey involved added manipulation and close inspection by the predator (see Juanes \& Conover 1994a for descriptions of fish-prey consumption). Shrimp tended to remain motionless on the tank bottom and would react to bluefish attacks by jumping up and away. Once captured, shrimp prey were often spat out and re-ingested before they could be swallowed. In contrast to the frequent observations of partial prey consumption of fish prey (Juanes \& Conover 1994a, Scharf et al. 1997), shrimp prey were always swallowed whole.

Attack success rates varied little across bluefish sizes (all p > 0.05) but strongly across prey types within a size class. Attacks on shrimp ( 20 to $25 \%$ ) were always less successful than attacks on silversides ( 60 to $65 \%)$ (small bluefish: $\mathrm{p}=0.0015$, df $=1,12, t=4.081$; large bluefish: $\mathrm{p}=0.017$, $\mathrm{df}=1,9, t=2.919$ ) (Fig. 1A). 

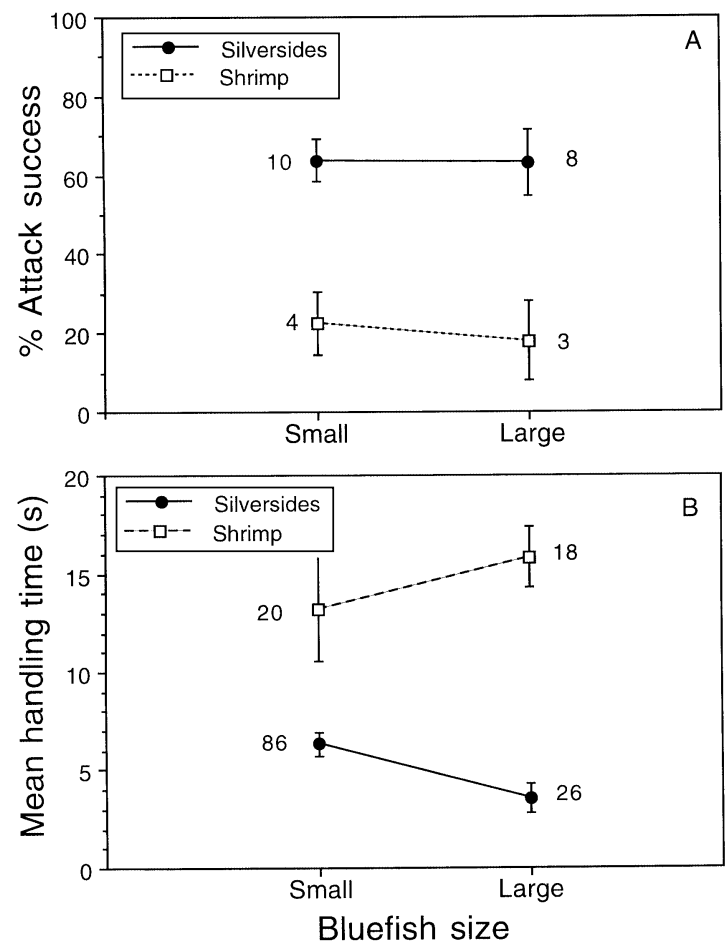

Fig. 1. Pomatomus saltatrix. Predation components for 2 sizes of bluefish feeding on similarly-sized silversides Menidia menidia and sand shrimp (Crangon septemspinosa) in those experiments where bluefish were offered 1 prey size at a time. Vertical bars: $\mathrm{SE}_{\text {; numbers: sample sizes }}$

Table 1. Pomatomus saltatrix. Total numbers of prey eaten by young-of-the-year bluefish (90 to $120 \mathrm{~mm}$ total length, TL) when given a choice of equal numbers of small $(20$ to $40 \mathrm{~mm}$ TL) and large (50 to $70 \mathrm{~mm}$ TL) sand shrimp (Crangon septemspinosa). ${ }^{*}$ Significant chi-squared values $(p<0.05)$

\begin{tabular}{|c|c|c|c|c|}
\hline \multirow{2}{*}{$\begin{array}{l}\text { Trial } \\
\text { no. }\end{array}$} & \multirow{2}{*}{$\begin{array}{c}\text { No. } \\
\text { of days }\end{array}$} & \multicolumn{2}{|c|}{ Nos. eaten } & \multirow[t]{2}{*}{$\chi^{2}$} \\
\hline & & Small & Large & \\
\hline 1 & 14 & 152 & 60 & $39.92^{*}$ \\
\hline 2 & 14 & 157 & 49 & $56.62^{*}$ \\
\hline 3 & 14 & 162 & 66 & $40.42^{*}$ \\
\hline Total & 42 & 471 & 175 & $135.63^{*}$ \\
\hline
\end{tabular}

Table 2. Pomatomus saltatrix. Total numbers of prey eaten by young-of-the-year bluefish (60 to $90 \mathrm{~mm} \mathrm{TL}$ ), when given a choice of equal numbers of 2 prey types, silversides (Menidia menidia) and sand shrimp (Crangon septemspinosa) of similar sizes (20 to $40 \mathrm{~mm}$ TL). ${ }^{*}$ Significant chi-squared values $(\mathrm{p}<0.05)$

\begin{tabular}{|lcccc|}
\hline \multirow{2}{*}{$\begin{array}{l}\text { Trial } \\
\text { no. }\end{array}$} & \multirow{2}{*}{$\begin{array}{c}\text { No. } \\
\text { of days }\end{array}$} & Menidia & Crangon & $\chi^{2}$ \\
\hline 1 & 11 & 89 & 7 & $70.04^{*}$ \\
2 & 7 & 64 & 6 & $48.06^{*}$ \\
Total & 18 & 153 & 13 & $118.07^{*}$ \\
\hline
\end{tabular}

We found no significant differences in mean handling times on shrimp prey between bluefish size classes ( $p=0.1519$, df $=1,36, t=1.464)$, but significant differences for fish prey handling times $(p=0.0222$, $\mathrm{df}=1,110, t=2.32$ ). Comparison within bluefish size classes revealed significant differences between prey types. Bluefish feeding on shrimp prey always had significantly higher handling times $(\sim 15 \mathrm{~s})$ than when feeding on fish prey ( $\sim \mathrm{s})$ (small bluefish: $\mathrm{p}=0.0003$, $\mathrm{df}=1,104, t=3.748$; large bluefish: $\mathrm{p}<0.00001$, df $=$ 1,42, $t=6.76$ ) (Fig. 1B).

Calculated profitabilities were higher for fish prey than for shrimp prey (Fig. 2A) and shrimp profitability declined to near 0 when attack success rates were incorporated into the profitability calculations (Fig. 2B).

Bluefish generally ate more smaller prey than expected by chance (Table 1). When given a choice between silversides and shrimp of similar sizes, bluefish exhibited a significant selection for silversides (Table 2).
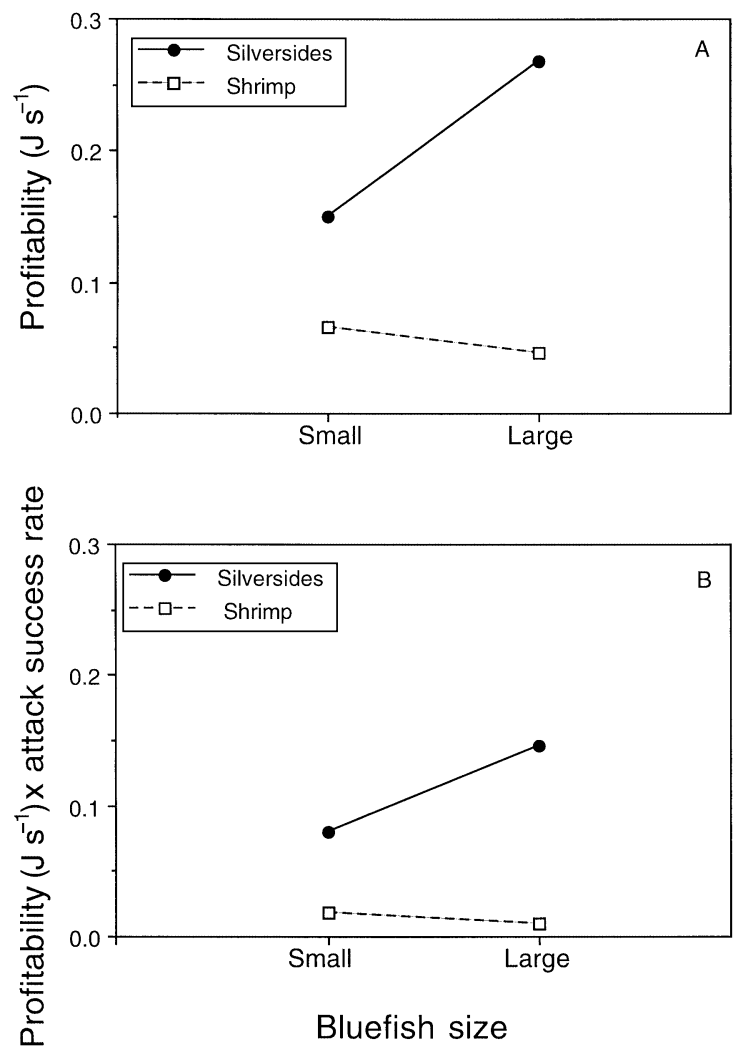

Fig. 2. Pomatomus saltatrix. Prey profitability for 2 sizes of bluefish feeding on similarly-sized silversides and sand shrimp calculated as the ratio of mean prey energy content to mean handling time from Fig. 1B (A) and weighted by attack success rate from Fig. 1A (B) 


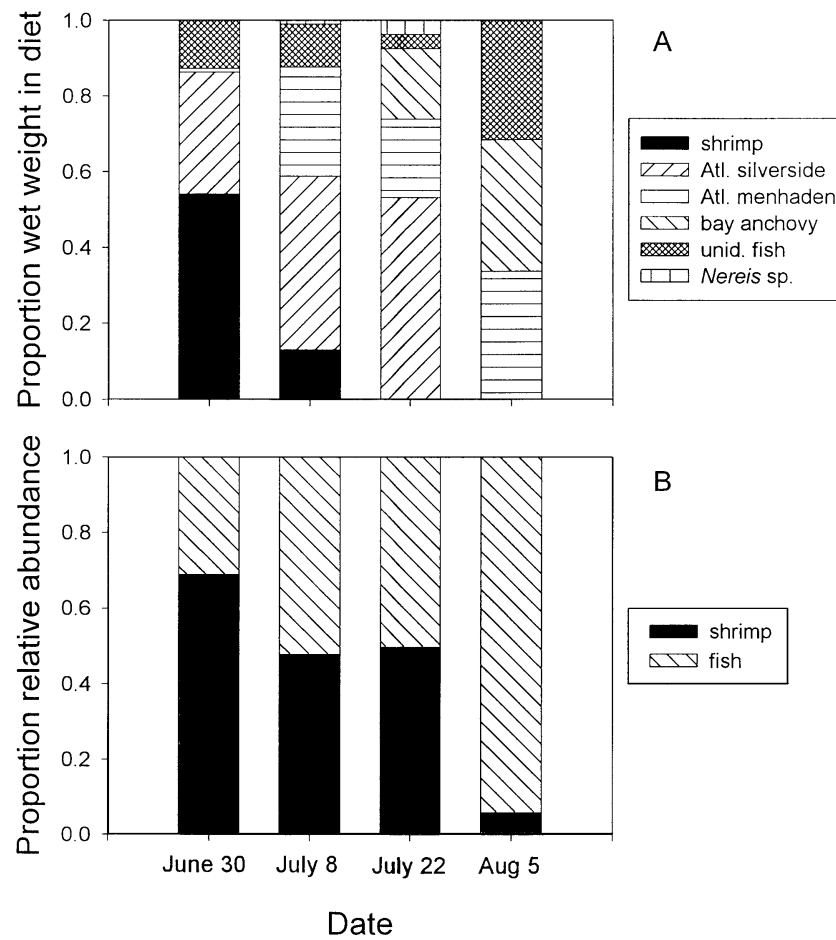

Fig. 3. Pomatomus saltatrix. Diet (proportion wet weight) of bluefish (A) and mean relative abundance of fish and shrimp prey (B) as a function of date

\section{Field collections and diet analysis}

The stomach contents of 79 YOY bluefish were examined. Diet was dominated by teleost fish and shrimp prey (Table 3, Fig. 3A). Fish prey included Atlantic silversides, bay anchovy Anchoa mitchilli and Atlantic menhaden, Brevoortia tyrannus while the only shrimp prey taken was sand shrimp. Relative abun- dance of shrimp was high in early summer but declined as fish abundance increased (Fig. 3B)

Spring-spawned YOY bluefish selected positively $(\alpha>0.5)$ for fish over shrimp prey ( $t$-test: mean $\alpha$ vs 0.5 , $\mathrm{p}<0.05$ ) on 3 out of 4 dates (Table 4, Fig. 4). Although the mean selectivity for fish was greater than 0.5 on July 8, 1999, there was no significant difference from random feeding (Fig. 4 ; $t$-test: mean $\alpha$ vs $0.5, p=0.390$ ).

Fish and shrimp prey lengths were plotted as functions of bluefish length (Fig. 5). There was no significant difference between the slopes of these relationships; however, there was a significant difference in their intercepts (ANCOVA, slopes: $\mathrm{p}=0.301$, $\mathrm{df}=1,62$, $F=1.09$; intercepts: $\mathrm{p}<0.0001, \mathrm{df}=1,63, F=176.4$ ), with fish prey always being larger than shrimp prey over the range of bluefish sizes examined.

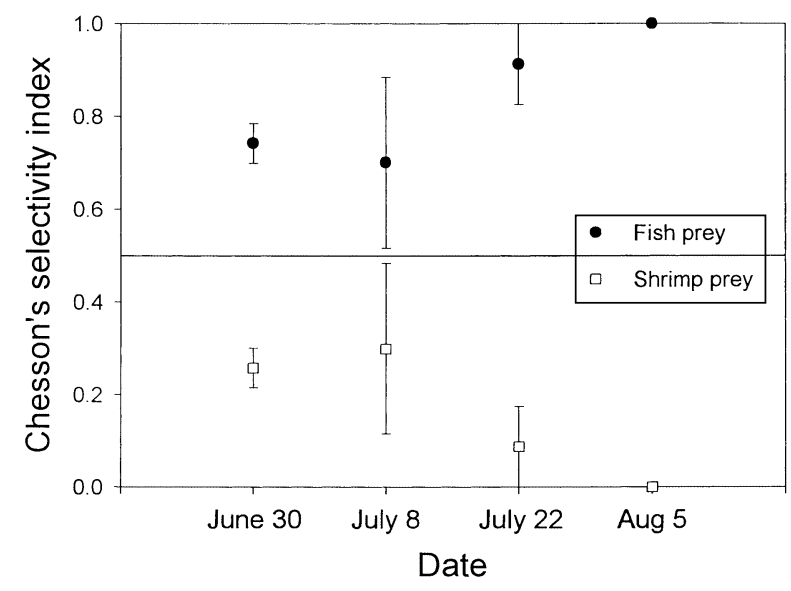

Fig. 4. Pomatomus saltatrix. Mean selectivity of bluefish on fish and shrimp prey by date. Horizontal line represents random feeding (0.5); Chesson's index values $>0.5$ represent positive selection, values $<0.5$ negative selection. Vertical bars: SE

Table 3. Pomatomus saltatrix. Diet of spring-spawned young-of-the-year (YOY) bluefish captured during 1999 collections in Great South Bay. Values are means of station values for a given date. F: frequency of occurrence; W: proportion wet weight

\begin{tabular}{|c|c|c|c|c|c|c|c|c|c|}
\hline \multirow{2}{*}{ Common name } & \multirow{2}{*}{ Scientific name } & \multicolumn{2}{|c|}{ June 30} & \multicolumn{2}{|c|}{ July 8} & \multicolumn{2}{|c|}{ July 22} & \multicolumn{2}{|c|}{ Aug 5} \\
\hline & & F & W & $\mathrm{F}$ & $\mathrm{W}$ & $\mathrm{F}$ & W & $\mathrm{F}$ & W \\
\hline Atlantic silverside (YOY) & Menidia menidia & 0.38 & 0.32 & 0.51 & 0.46 & 0.32 & 0.53 & & \\
\hline Bay anchovy & Anchoa mitchilli & & & & & 0.24 & 0.19 & 0.33 & 0.35 \\
\hline Atlantic menhaden & Brevoortia tyrannus & 0.02 & 0.01 & 0.29 & 0.29 & 0.19 & 0.21 & 0.33 & 0.34 \\
\hline Unidentified fish remains & & 0.13 & 0.13 & 0.16 & 0.11 & 0.12 & 0.04 & 0.67 & 0.32 \\
\hline Sand shrimp & Crangon septemspinosa & 0.69 & 0.54 & 0.38 & 0.13 & 0.03 & 0.01 & & \\
\hline Sand worm & Nereis virens & & & 0.04 & 0.01 & 0.06 & 0.04 & & \\
\hline \multicolumn{2}{|l|}{ No. of bluefish } & \multicolumn{2}{|c|}{28} & \multicolumn{2}{|c|}{19} & \multicolumn{2}{|c|}{23} & \multicolumn{2}{|c|}{9} \\
\hline \multicolumn{2}{|c|}{ No. with prey } & \multicolumn{2}{|c|}{26} & \multicolumn{2}{|c|}{19} & \multicolumn{2}{|c|}{18} & \multicolumn{2}{|c|}{9} \\
\hline \multicolumn{2}{|c|}{ Mean bluefish total length (mm, SD) } & \multicolumn{2}{|c|}{$95.4(22.2)$} & \multicolumn{2}{|c|}{$121.1(7.7)$} & \multicolumn{2}{|c|}{$153.3(14.0)$} & \multicolumn{2}{|c|}{$163(19.9)$} \\
\hline \multicolumn{2}{|c|}{ Total length range $(\mathrm{mm})$} & \multicolumn{2}{|c|}{$61-142$} & \multicolumn{2}{|c|}{$107-139$} & \multicolumn{2}{|c|}{$123-186$} & \multicolumn{2}{|c|}{$142-206$} \\
\hline \multicolumn{2}{|c|}{ Mean bluefish weight $(g, S D)$} & \multicolumn{2}{|c|}{$9.1(6.3)$} & \multicolumn{2}{|c|}{$16.9(3.26)$} & \multicolumn{2}{|c|}{$34.6(11.4)$} & \multicolumn{2}{|c|}{$44.8(17.7)$} \\
\hline \multicolumn{2}{|c|}{ Weight range $(\mathrm{g})$} & \multicolumn{2}{|c|}{$2.0-26.2$} & \multicolumn{2}{|c|}{$10.8-24.6$} & \multicolumn{2}{|c|}{$17.2-64.0$} & \multicolumn{2}{|c|}{$28.3-86.8$} \\
\hline
\end{tabular}


Table 4. Mean density of fish (Atlantic silverside, Menidia menidia, bay anchovy, Anchoa mitchilli, and clupeids) and shrimp (sand and grass shrimp, Crangon septemspinosa and Palaemonetes vulgaris) prey types, and mean Chesson's selectivity $(\alpha)$ of young-of-the-year bluefish on these prey by date and collection site during 1999 in Great South Bay. Random feeding occurs when mean $\alpha=0.5$; values of $\alpha>0.5$ or $<0.5$ represent 'selection' and 'avoidance' of prey, respectively. Mean selectivities for each date are shown in Fig. 4

\begin{tabular}{|llcccc|}
\hline $\begin{array}{l}\text { Date } \\
(1999)\end{array}$ & Site & $\begin{array}{c}\text { Fish } \\
\text { density } \\
\left(\# \mathrm{~m}^{-2}\right)\end{array}$ & $\begin{array}{c}\text { Shrimp } \\
\text { density } \\
\left(\# \mathrm{~m}^{-2}\right)\end{array}$ & $\begin{array}{c}\text { Selectivity } \\
\text { on fish } \\
(\alpha)\end{array}$ & $\begin{array}{c}\text { Selectivity } \\
\text { on shrimp } \\
(\alpha)\end{array}$ \\
\hline June 30 & Pine Neck & 3.59 & 17.58 & 0.66 & 0.34 \\
June 30 & Fireplace Neck & 0.47 & 14.88 & 0.81 & 0.19 \\
June 30 & Smith Point & 2.95 & 1.31 & 0.76 & 0.24 \\
July 8 & Smith Point & 4.37 & 14.29 & 0.93 & 0.07 \\
July 8 & Bayshore & 0.28 & 0.52 & 1.0 & 0 \\
July 8 & Fireplace Neck & 0.41 & 0.22 & 0.69 & 0.31 \\
July 8 & Pine Neck & 1.59 & 0.36 & 0.18 & 0.82 \\
July 22 & Smith Point & 1.03 & 5.57 & 1.0 & 0 \\
July 22 & Fireplace Neck & 1.69 & 0.07 & 1.0 & 0 \\
July 22 & Bayshore & 0.15 & 1.15 & 1.0 & 0 \\
July 22 & Pine Neck & 0.42 & 0.13 & 0.65 & 0.35 \\
August 5 & Pine Neck & 0.57 & 0.10 & 1.0 & 0 \\
August 5 & Smith Point & 3.2 & 0.10 & 1.0 & 0 \\
August 5 & Fireplace Neck & 2.7 & 0.03 & 1.0 & 0 \\
\hline
\end{tabular}

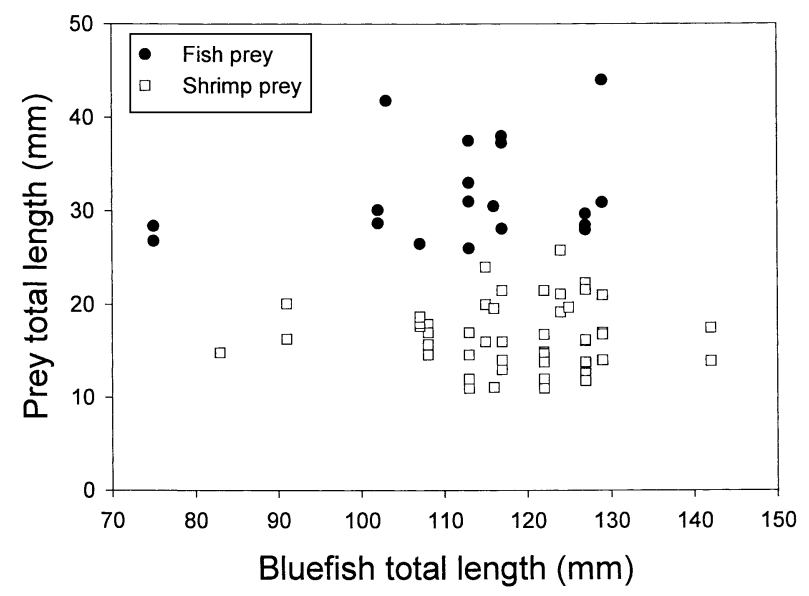

Fig. 5. Pomatomus saltatrix. Prey total length versus bluefish total length for fish and shrimp prey. ANCOVA found no differences between slopes, but intercepts were significantly different (slopes: $F=1.09, \mathrm{df}=1,62, \mathrm{p}=0.301$; intercepts: $F=$ $176.4, \mathrm{df}=1,63, \mathrm{p}<0.0001)$

\section{DISCUSSION}

Juvenile bluefish Pomatomus saltatrix, like other primary piscivorous fishes often consume other non-fish prey, including zooplankton and macroinvertebrates (Friedland et al. 1988, Creaser \& Perkins 1994, Juanes \& Conover 1994a, 1995, Buckel et al. 1999). For example, the diets of certain northern pike Esox lucius populations can consist almost entirely of invertebrate prey on a seasonal basis (Chapman et al. 1989), and largemouth bass (Micropterus salmoides) diets commonly include large proportions of terrestrial vertebrate prey (primarily amphibians; Hodgson et al. 1997) and crayfish (Hoyle \& Keast 1987, Ward \& Neumann 1998, Yako et al. 2000). Although most piscivores feed on non-fish prey before undergoing an ontogenetic diet shift to piscivory (Mittelbach et al. 1988, Post et al. 1997, St. John 1999), feeding on non-piscine prey is not limited to only smaller predators, but is frequently observed in larger predators (Chapman et al. 1989, Eggleston et al. 1998, Beaudoin et al. 1999).

Our behavioural observations suggest that shrimp prey are more difficult to handle and ingest than fish prey, resulting in much lower capture-success rates, longer handling times, and, as a consequence, lower profitabilities. However, similar to the patterns observed for bluefish (Juanes et al. 1994, Scharf et al. 1997) and other piscivores feeding on fish prey (Juanes 1994), small shrimp prey are selectively ingested over larger shrimp prey both in the laboratory (this study) and in the field (Juanes \& Conover 1995). When comparing crayfish and fish prey in largemouth bass diets, Hoyle \& Keast (1987) also found that crayfish had the highest handling times and lowest profitabilities and that small prey sizes of both prey types were selectively consumed in the field, although they did not measure prey type selectivity.

Predator-prey interactions can be strongly determined by prey morphology and behaviour (Sih \& Moore 1990). The results of the laboratory prey-type selection experiments show that YOY bluefish consistently ingest more silversides than shrimp when given a choice of similarly-sized individuals, as predicted by their relative profitabilities. In the field, shrimp prey ingested were considerably smaller than fish prey consumed, perhaps due to smaller average shrimp sizes (not measured in this study, but see field-size frequency distributions in Juanes \& Conover 1995). Preyspecific evacuation rates do not differ for bluefish feeding on silversides (Menidia menidia) and sand shrimp (Crangon septemspinosa) (Juanes \& Conover 1994b); therefore, in contrast to other fish predators (Lankford \& Targett 1997) post-ingestion processes are apparently not important determinants of prey choice in this species. The relative vulnerability of these prey types may instead be due to species-specific differences in prey response and swimming behaviour. Silversides 
respond to attack by changing direction and increasing speed while a shrimp's escape behaviour is usually a burst of movement from a motionless position. The escape response of a constantly swimming prey such as a silverside may be less flexible than that of shrimp because the direction of escape is largely determined by its trajectory. By accelerating from a set position, shrimp can move in a number of directions and thereby incorporate unpredictable elements into their escape response (see Arnott et al. 1998, 1999). The relative immobility exhibited by shrimp in the presence of a predator may also reduce detection, since many fish predators are attracted to movement (Keenleyside 1979).

The increased handling times and lower success rates associated with consuming shrimp must also be reflected in additional foraging costs. Although these costs were not directly measured, bluefish fed shrimp prey display lower feeding and growth rates than those fed silversides as prey (Juanes \& Conover 1994b). In addition, in a field study comparing growth and diet, juvenile bluefish were heavier at length (i.e. had higher condition factors) when fish, rather than macroinvertebrates (primarily sand shrimp, the grass shrimp Palaemonotes vulgaris, and the opossum shrimp Neomysis americana) dominated their diets (Friedland et al. 1988).

The diet of juvenile bluefish in 1999 was dominated by Atlantic silversides, bay anchovy Anchoa mitchilli, Atlantic menhaden Brevoortia tyrannus, and shrimp; this diet is similar to that described for bluefish in Great South Bay in past years (Juanes \& Conover 1995) and in other New York Bight estuaries (Friedland et al. 1988). The exception is the presence of Atlantic menhaden in the diet, which has not been reported previously for this region but has been found to be a dominant prey of YOY bluefish in other systems (Grant 1962, Hartman \& Brandt 1995). We conclude that in Great South Bay, the annual availability of Atlantic menhaden may not be as consistent as the occurrence of Atlantic silversides and bay anchovy.

The results of our field collections corroborate our laboratory findings. We found significant positive selection for fish prey and negative selection for shrimp prey even though shrimp were often much more abundant in field collections (an order of magnitude higher than fish prey on some dates). However, the extent of fish and shrimp feeding does appear to be correlated with their relative abundances. As shrimp abundances declined and fish abundances increased, consumption of shrimp decreased whereas fish consumption increased. These observed selectivity patterns suggest that relative consumption of different prey types is 'opportunistic' and that the pattern of selection is the result of passive processes. When given the choice of 2 prey sizes (Juanes \& Conover 1994a) or 2 fish species (Bell et al. 1999), bluefish have been shown to attack them at equal rates, so that relative capture success rates determine the probability of ingestion. Silverside and shrimp prey are also probably attacked at similar rates. Thus, even when prey abundances are similar, more fish than shrimp prey are consumed because of the higher capture success on fish prey. Similarly, when shrimp prey are very abundant, more shrimp than fish prey are ingested, but mean selectivity for shrimp prey remains low. Previous work in the Hudson River estuary also showed that YOY bluefish diets were a reflection of the relative abundance of their prey species (Juanes et al. 1993).

The observed prey selectivities combined with the patterns of prey abundance in the field may have important implications for recruitment of YOY bluefish. Small bluefish entering estuaries early in the season are more likely to encounter and therefore ingest more shrimp than fish prey, particularly if shrimp are very abundant and small in size compared to available fish prey. However, because differences in profitability between fish and shrimp prey are smaller for smaller bluefish (Fig. 2), and growth is reduced when piscivory is delayed (Buckel et al. 1998), the continued ingestion of shrimp prey could lead to lower growth (Friedland et al. 1988, Juanes \& Conover 1994b). We conclude that the timing of bluefish entry into estuaries relative to peaks in abundance of various prey could have a strong effect on bluefish size at the end of the growing season and therefore size-dependent survival.

Research on foraging theory has focused mainly on the role of predator habitat and diet choice, while the factors affecting encounter probabilities have received comparatively less attention (Persson \& Diehl 1990). The results of this study agree with Sih \& Moore's (1990) suggestion that in many cases prey behaviour may be as important as predator choice in determining predator diets. A re-analysis of a literature review in Stephens \& Krebs (1986) conducted by Sih \& Moore showed that, in general, when prey are mobile predictions derived from optimal diet theory do not work as well as when prey are less mobile. This conclusion suggests that future studies of mobile predator/prey systems (such as piscivorous fishes and their prey) should include prey behaviours that influence capture success and encounter rates and ultimately determine predator selectivities.

Acknowledgements. We thank the many people who helped with the laboratory experiments and field collections. Our gratitude to D. Conover for his encouragement and support, and to J. Yen for use of her video analysis equipment. Brian Hanrahan, Al Stoner and 2 anonymous reviewers offered numerous helpful suggestions on earlier versions of the man- 
uscript. This work was funded by a graduate fellowship in population biology from the Electric Power Research Institute (to F.J.), by the Office of Sea Grant, National Oceanic and Atmospheric Administration, under grant NA86AA-D-SG045 to the New York Sea Grant Institute (to Dave Conover), by a research grant from the Hudson River Foundation for Science and Environmental Research Inc. (to F.J.), and by the Nature Conservancy of Long Island through support from the Eppley Foundation (to J.A.B.).

\section{LITERATURE CITED}

Arnott SA, Neil DM, Ansell AD (1998) Tail-flip mechanism and size-dependent kinematics of escape swimming in the brown shrimp Crangon crangon. J Exp Biol 201: 1771-1784

Arnott SA, Neil DM, Ansell AD (1999) Escape trajectories of the brown shrimp Crangon crangon, and a theoretical consideration of initial escape angles from predators. J Exp Biol 202:193-209

Beaudoin CP, Tonn WM, Prepas EE, Wassenaar LI (1999) Individual specialization and trophic adaptability of northern pike (Esox lucius): an isotope and dietary analysis. Oecologia 120:386-396

Beets J (1997) Effects of a predatory fish on the recruitment and abundance of Caribbean coral reef fishes. Mar Ecol Prog Ser 148:11-21

Bell GW, Buckel JA, Stoner AW (1999) Effects of alternative prey on cannibalism in age-1 bluefish. J Fish Biol 55: 990-1000

Brönmark C, Miner JG (1992) Predator-induced phenotypical change in body morphology in crucian carp. Science 258: 1348-1350

Buckel JA, Conover DO (1997) Movements, feeding periods, and daily ration of piscivorous young-of-the-year bluefish, Pomatomus saltatrix, in the Hudson River estuary. Fish Bull (Wash DC) 95:665-679

Buckel JA, Letcher, BH, Conover, D (1998) Effects of a delayed onset of piscivory on the size of age-0 bluefish. Trans Am Fish Soc 127:576-587

Buckel JA, Fogarty MJ, Conover DO (1999) Foraging habits of bluefish, Pomatomus saltatrix, on the U.S. east coast continental shelf. Fish Bull (Wash DC) 97:758-775

Carpenter SR, Kitchell JF (1993) The trophic cascade in lakes. Cambridge University Press, New York

Carr MH, Hixon MA (1995) Predation effects on early postsettlement survivorship of coral-reef fishes. Mar Ecol Prog Ser 124:31-42

Chapman LJ, Mackay WC, Wilkinson CW (1989) Feeding flexibility in northern pike (Esox lucius): fish versus invertebrate prey. Can J Fish Aquat Sci 46:666-669

Chesson J (1978) Measuring preference in selective predation. Ecology 59:211-215

Chesson J (1983) The estimation and analysis of preference and its relationship to foraging models. Ecology 64: $1297-1304$

Connell SD (1998) Effects of predators on growth, mortality and abundance of a juvenile reef fish: evidence from manipulations of predator and prey abundance. Mar Ecol Prog Ser 169:251-261

Creaser EP, Perkins HC (1994) The distribution, food, and age of juvenile bluefish, Pomatomus saltatrix, in Maine. Fish Bull (Wash DC) 92:494-508

Dill LM (1983) Adaptive flexibility in the foraging behavior of fishes. Can J Fish Aquat Sci 40:398-408
Eggleston DB, Grover JJ, Lipcius RN (1998) Ontogenetic diet shifts in Nassau grouper: trophic linkages and predatory impact. Bull Mar Sci 63:111-126

Ellis T, Gibson RN (1995) Size-selective predation of 0-group flatfishes on a Scottish coastal nursery ground. Mar Ecol Prog Ser 127:27-37

Ellis T, Gibson RN (1997) Predation of 0-group flatfishes by 0group cod: handling times and size-selection. Mar Ecol Prog Ser 149:83-90

Fitzhugh GR, Crowder LB, Monaghan JP (1996) Mechanisms contributing to variable growth in juvenile southern flounder (Paralichthys lethostigma). Can J Fish Aquat Sci 53: 1964-1973

Friedland KD, Garman GC, Bejda AJ, Studholme AL, Olla B (1988) Interannual variation in diet and condition in juvenile bluefish during estuarine residency. Trans Am Fish Soc 117:474-479

Gerking SD (1994) Feeding ecology of fish. Academic Press, San Diego

Grant GC (1962) Predation of bluefish on young Atlantic menhaden in Indian River, Delaware. Chesapeake Sci 3: $45-47$

Hambright KD (1994) Morphological constraints in the piscivore-planktivore interaction: implications for the trophic cascade hypothesis. Limnol Oceanogr 39:897-912

Hartman KJ, Brandt SB (1995) Trophic resource partitioning, diets, and growth of sympatric estuarine predators. Trans Am Fish Soc 124:520-537

Hodgson JR, Schindler DE, Kitchell JF (1997) Diet overlap in a piscivore community. Ecol Freshw Fish 6:144-149

Hoyle JA, Keast A (1987) The effect of prey morphology and size on handling time in a piscivore, the largemouth bass (Micropterus salmoides). Can J Zool 65:1972-1977

Jennings S, Kaiser MJ (1998) The effects of fishing on marine ecosystems. Adv Mar Biol 34:201-352

Johnson JB, Belk MC (1999) Effects of predation on life-history evolution in Utah chub (Gila atraria). Copeia 1999: 948-957

Juanes $F$ (1994) What determines prey size selectivity in piscivorous fishes? In: Stouder DJ, Fresh KL, Feller RJ (eds) Theory and application in fish feeding ecology. S Carolina University Press, Columbia, p 79-100 (Belle W. Baruch Library in Marine Sciences No. 18)

Juanes F, Buckel JA, Conover DO (1994) Accelerating the onset of piscivory: intersection of predator and prey phenologies. J Fish Biol 45 (Suppl. A):41-54

Juanes F, Conover DO (1994a) Piscivory and prey size selection by young-of-the-year bluefish: predator preference or size-dependent capture success? Mar Ecol Prog Ser 114: $59-69$

Juanes F, Conover DO (1994b) Rapid growth, high feeding rates, and early piscivory in young-of-the-year bluefish (Pomatomus saltatrix). Can J Fish Aquat Sci 51:1752-1761

Juanes F, Conover DO (1995) Size-structured piscivory: advection and the linkage between predator and prey recruitment in young-of-the-year bluefish. Mar Ecol Prog Ser 128:287-304

Juanes F, Marks RE, McKown KA, Conover DO (1993) Predation by age- 0 bluefish on age- 0 anadromous fishes in the Hudson River estuary. Trans Am Fish Soc 122:348-356

Keast A (1985) The piscivore guild of fishes in small freshwater ecosystems. Environ Biol Fish 12:119-129

Keenleyside MHA (1979) Diversity and adaptation in fish behaviour. Springer-Verlag, New York

Lankford TE, Targett TE (1997) Selective predation by juvenile weakfish: post-consumptive constraints on energy maximization and growth. Ecology 78:1049-1061 
Malmquist HJ, Snorrason SS, Skulason S, Jonsson B, Sandlund OT, Jonasson PM (1992) Diet differentiation in polymorphic Arctic charr in Thingvallavatn, Iceland. J Anim Ecol 61:21-35

Marks RE, Conover DO (1993) Ontogenetic shift in the diet of young-of-year bluefish Pomatomus saltatrix during the oceanic phase of the early life history. Fish Bull (Wash DC) 91:97-106

McDermott JJ (1983) Food web in the surf zone of an exposed sandy beach along the mid-Atlantic coast of the United States. In: McLachlan A, Erasmus T (eds) Sandy beaches as ecosystems. W. Junk, The Hague, p 529-537

Mittelbach GG, Osenberg CW, Leibold MA (1988) Trophic relations and ontogenetic niche shifts in aquatic ecosystems. In: Ebenman B, Persson L (eds) Size-structured populations. Springer-Verlag, Berlin, p 219-233

Mittelbach GG, Turner AM, Hall DJ, Rettig JE, Osenberg CW (1995) Perturbation and resilience: a long-term wholelake study of predator extinction and reintroduction. Ecology $76: 2347-2360$

Olson MH (1996) Ontogenetic shifts in largemouth bass: variability and consequences for first-year growth. Ecology 77:179-190

Persson L, Diehl S (1990) Mechanistic individual-based approaches in the population/community ecology of fish. Ann Zool Fenn 27:165-182

Poleo ABS, Øxnevad SA, Østbye K, Heibo E, Andersen RA, Vollestad LA (1995) Body morphology of crucian carp Carassius carassius in lakes with or without piscivorous fish. Ecography 18:225-229

Post DM, Carpenter SR, Christensen DL, Cottingham KL, Kitchell JF, Schindler DE (1997) Seasonal effects of variable recruitment of a dominant piscivore on pelagic food web structure. Limnol Oceanogr 42:722-729

Rodd FH, Reznick DN (1997) Variation in the demography of guppy populations: the importance of predation and life histories. Ecology 78:405-418

Scharf FS, Buckel JA, Juanes F, Conover DO (1997) Estimating piscine prey size from partial remains: testing for shifts in foraging mode by juvenile bluefish. Environ Biol Fish $49: 377-388$

Editorial responsibility: Colin Levings (Contributing Editor), West Vancouver, Canada
Scharf FS, Juanes F, Sutherland M (1998a) Inferring ecological relationships from the edges of scatter diagrams: comparison regression techniques. Ecology 79:448-460

Scharf FS, Buckel JA, Juanes F, Conover DO (1998b) Predation by juvenile piscivorous bluefish (Pomatomus saltatrix): the influence of prey to predator size ratio and prey type on predator capture success and prey profitability. Can J Fish Aquat Sci 55:1695-1703

Sih A, Moore RD (1990) Interacting effects of predator and prey behavior in determining diets. In: Hughes RN (ed) Behavioural mechanisms of food selection. Springer-Verlag, Berlin, p 771-796. (NATO ASI Ser Ser G Ecol Sci No. 20)

Sogard SM (1997) Size-selective mortality in the juvenile stage of teleost fishes: a review. Bull Mar Sci 60: $1129-1157$

St. John J (1999) Ontogenetic changes in the diet of the coral reef grouper Plectropomus leopardus (Serranidae): patterns in taxa, size and habitat of prey. Mar Ecol Prog Ser 180:233-246

Steimle FW, Terranova RJ (1985) Energy equivalents of marine organisms from the continental shelf of the temperate Northwest Atlantic. J Northwest Atl Fish Sci 6: $117-124$

Stephens DW, Krebs JR (1986) Foraging theory. Princeton University Press, Princeton

Ward SM, Neumann RM (1998) Seasonal and size-related food habits of largemouth bass in two Connecticut lakes. J Freshw Ecol 13:213-220

Werner EE, Gilliam JF (1984) The ontogenetic niche and species interactions in size-structured populations. Annu Rev Ecol Syst 15:393-425

Wright RA, Crowder LB, Martin TH (1993) The effects of predation on the survival and size-distribution of estuarine fishes: an experimental approach. Environ Biol Fish 36: 291-300

Yako LA, Mather MA, Juanes F (2000) Assessing the contribution of anadromous herring to largemouth bass growth. Trans Am Fish Soc 129:77-88

Zar JH (1984) Biostatistical analysis. Prentice-Hall, Englewood Cliffs, NJ

Submitted: January 6, 2000; Accepted: October 20, 2000 Proofs received from author(s): July 10, 2001 